\title{
Scanning Electron Microscopic Examinations of Microvascular Casts of the Rat Liver and Bile Duct
}

\author{
Joji Haratake, Osamu Yamamoto, Masanori Hisaoka and Akio Horie \\ Department of Pathology and Oncology, School of Medicine, \\ University of Occupational and Environmental Health, Japan. Kitakyushu 807, Japan
}

Abstract: Microvascular features of normal rat livers and bile duct system were examined with the vascular casts using methacrylated resin. Portal vein branches not only showed regular tapered down bifurcations but also had many side branches, some of which were directly connected with sinusoids. Terminations of hepatic arterial branches were divided into three types: 1) Many branches pouring into peribiliary capillary plexus (PBP), 2) branches directly pouring into periportal sinusoids and/or peripheral portal vein branches via arterio-portal anastomoses, and 3) anastomoses with periportal vascular plexus. PBP was composed of rich vascular networks. In large portal tracts, the plexus showed two layers, that is, the inner layer made up of a close network of capillary vessels and the outer layer consisting of a loose network of arteries and veins, while the PBP in the small portal tracts was composed of only a single layer of loose capillary network. Transitional features of these two patterns were found in the medium-sized portal tracts. PBP was supplied by afferent vessels from the interlobular hepatic artery as described above, and were directly connected with interlobular branches of the portal vein (internal root). The extrahepatic bile duct revealed a much richer vasculature than the intrahepatic bile duct. Both arterial and venous branches were ramified at almost right angle from a pair of arteries and veins running parallel with the bile duct. Occasional strictures, which might have been sphincter portions of the media, were noted at the branching sites of the artery. The orfice of the common bile duct at the Vater's ampulla was a small hole-like structure surrounded by a single circular layer of capillary network. Since branchings and anastomoses of the hepatic artery as well as the portal vein were much more complicated than those previously reported, we described several discrepancies between literatures.

Key words: scanning electron microscopy, microvascular cast, liver, peribiliary plexus.

(Received 30 October 1989, accepted 25 December, 1989)

\section{Introduction}

Microvasculature of the liver has been studied for many years both by injections of dyes or polymers and light microscopic examinations of serial sections (Olds \& Stafford, 1930; Andrews et al., 1949; Elias \& Petty, 1953). Although such methods have provided much useful morphological information as to the three-dimensional hepatic microcirculatory system, recent advances in scanning electron microscopy and a new technique of corrosion castings have made possible further examination (Murakami et al., 1974; Kardon \& Kessel, 1980).

The hepatic circulation is characterized by a dual supply via the portal vein and hepat- 
ic artery, complicated anastomoses of sinusoids, and a rich vascular plexus around the bile ducts (Rappaport, 1980). In spite of precise examinations by scanning electron microscopy of cast specimens of the hepatic microcirulatory system, there are still some controversies over a number of problems, e. g. terminations of hepatic artery, afferent and efferent routes of periductal plexus, communications between the hepatic artery and hepatic vein branches etc (Murakami et al., 1974; Kardon \& Kessel, 1980; Yamamoto et al., 1985). In addition, some minor variations among species have been reported (Hojo et al., 1982; Ohtani et al., 1983; Yamamoto et al., 1985).

On these grounds, we examined the microvasculature of the liver and bile duct by scanning electron microscopy of cast specimens and describe new information concerning hepatic microcirculation with special reference to arterial terminations and periductal vascular plexuses.

\section{Materials and Methods}

The preparation of microvascular casts were made according to the method of Murakami (1971) with a few modifications. Thirty Wistar male rats, aged 8 weeks and weighing about $200 \mathrm{~g}$, were anesthetized by intraperitoneal injection of sodium pentobarbital $(50 \mathrm{mg} / \mathrm{kg}$ body weight). After opening both abdominal and thoracic cavities, a cannulation from the thoracic aorta and a cut down of the heart were performed. Circulating blood was fully flushed out with heparinized saline $(0.5 \mathrm{ml} / \mathrm{s})$, and methacrylated resin (Mercox CL-2B; Vilene Hospital, Tokyo) was infused into the vessel by syringes under constant manual pressure $(0.5 \mathrm{ml} / \mathrm{s})$. The liver, extrahepatic bile duct, stomach, duodenum, and pancreas were removed carefully en bloc after a complete polymerization of resin, and were fixed in $10 \%$ formalin for $24 \mathrm{hrs}$. The fixed livers were cut into slices, while the extrahepatic bile duct was pursued up to the Papilla vateri and preserved en bloc with the duodenum including the Papilla vateri and the pancreatic tissues around the bile duct. Fixed materials were then treated with $20 \%$ sodium hydroxide for $24 \mathrm{hrs}$ in a chamber at $60^{\circ} \mathrm{C}$. After the tissues were macerated, they were rinsed and dried in either air or a freezedryer (Eiko ID-2). In the latter case, macerated materials were repeatedly immersed in 2-methyl-2-propanol (t-butyl alcohol) before drying. Small pieces of the dried tissues were mounted on metal stubs under a dissecting microscope, coated with $5 \mathrm{~nm}$ of platinum, and observed under a scanning microscope, Hitachi S-700, with an accelerating voltage of $20 \mathrm{kV}$.

\section{Results}

A survey on the low power view exhibited orderly distributed portal tracts and radiated sinusoids from the terminal hepatic venules. The large portal tracts including large portal venous and hepatic arterial branches were scattered near the hepatic hilus. On the sur- 
face of the liver, sinusoids and terminal hepatic venules were readily seen, but portal tracts were few in number. The arterial branches were distinguished from venous ones by carefully tracing them up to the larger branches and by the different morphology of their surface impressions; relatively deep longitudinal impressions by endothelial nuclei were observed on the arterial surfaces. Portal vein branches were divided into smaller branches and tapered down. In addition, they had many side branches of various sizes, some of which directly poured into the sinusoids (Fig. 1). Most of these side branches were not accompanied by arterial branches. Around the portal vein branches, especially the large ones, loosely anastomosing vessels (periportal plexus) were noted (Figs. 2 and 3).

Bile ducts were realized as tube-like structures consisting of dense vascular mesh, namely peribiliary plexus, in the portal tracts. In the large portal tracts, peribiliary plexuses were formed as two layers; the outer layer was composed of a relatively scarce distribution of arteries and veins, and the inner one showed a close network of capillary vessels (Figs. 1 and 2). Peribiliary plexus was supplied by arterial branches, periodically ramified from interlobular hepatic arteries (Fig. 2), and was also directly connected with the portal vein (Fig. 3), especially with its side branches. In addition, peribiliary plexuses had many anastomoses with periportal vascular plexus (Fig. 2) and sinusoids. In the small portal tracts, the peribiliary plexuses were recognized as a sparse single layer network of capillaries (Fig. 4). In these small portal tracts, peripheral branches of the interlobular artery had direct connections with portal vein branches, that is arterio-portal fistula (Fig. 5), or with sinusoids near the portal tracts in Rappaport zone I. The interlobular arteries of the small portal tracts were occasionally derived from the peribiliary plexus rather than from the proximal hepatic arterial branches. Thus the terminations of the hepatic artery were roughly divided into three types. The first was periodical branches flowing into the peribiliary plexus supplying the intrahepatic bile ducts, the second type was the direct termination into the portal vein, i. e. arterio-portal fistula in the peripheral portal tracts, and the third route was ramification to the periportal plexus. Sinusoids showed extremely complex anastomoses and converged upon the terminal hepatic venules. No direct connections were found between the terminal hepatic venules and portal vein or hepatic artery branches.

Extrahepatic bile ducts showed a denser vascular network than large portions of the intrahepatic bile duct; an artery and a vein ran parallel with the bile ducts, and segmental branches were ramified perpendicularly from each vessel (Fig. 6). At the branching sites of the artery, there were occasional strictures, possibly sphincter apparatuses (Fig. 7). Periductal vessels were connected with the surrounding pancreatic vessels.

On the mucosal surface of the duodenum, there were numerous intestinal villi rich in capillary vessels. These capillary networks of the villi often collapsed and lost their natural configurations when air-dried, but were well preserved when freeze-dried after being immersed in t-butyl alcohol, as done in this study. Each duodenal villus represented a plane petal-shaped mesh. At the portion of the Vater's ampulla, there was a small hole which 


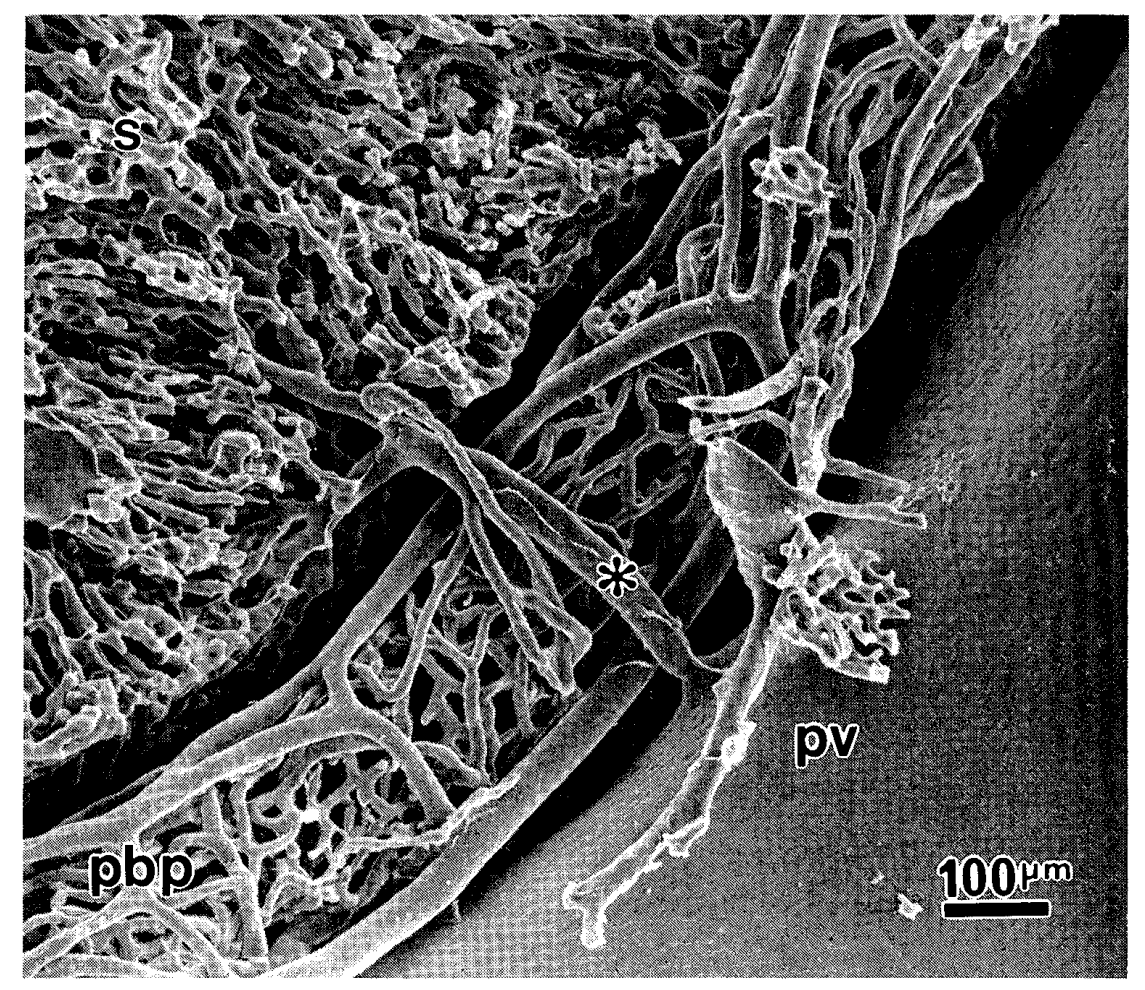

Fig. 1. A large portal tract. Peribiliary plexus consists of two layers, the outer layer of the arterial and venous network and inner layer of the fine capillary plexus. Note a small side branch $(*)$ of the portal vein directly flowing into the sinusoid. Abbreviations: pv (portal vein), pbp (peribiliary plexus), s (sinusoid).

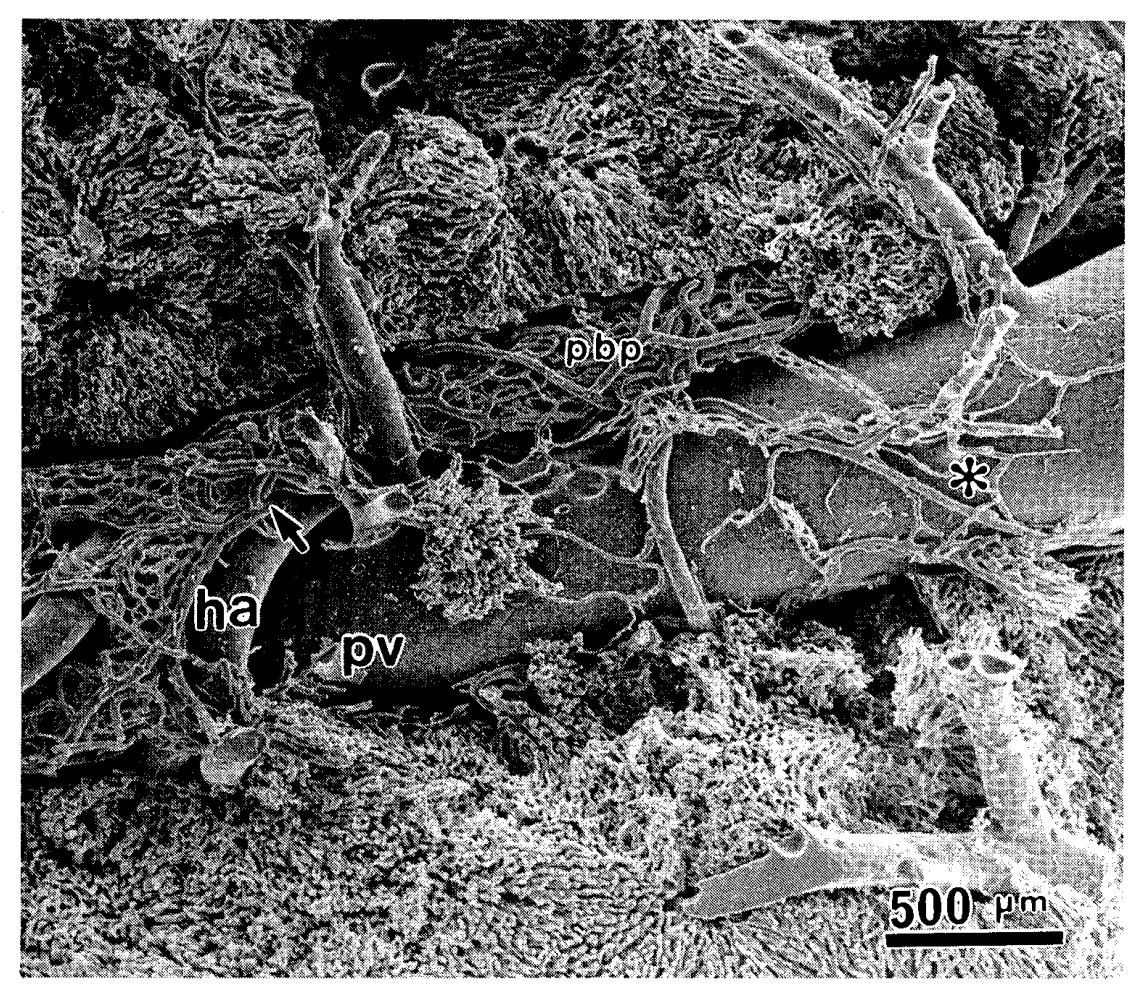

Fig. 2. A dividing portion of a large portal tract. The hepatic artery gives off an arterial branch to the peribiliary plexus (arrow) and to the periportal plexus ( $*$ ). Abbreviations: ha (hepatic artery), others (same as in Fig. 1). 


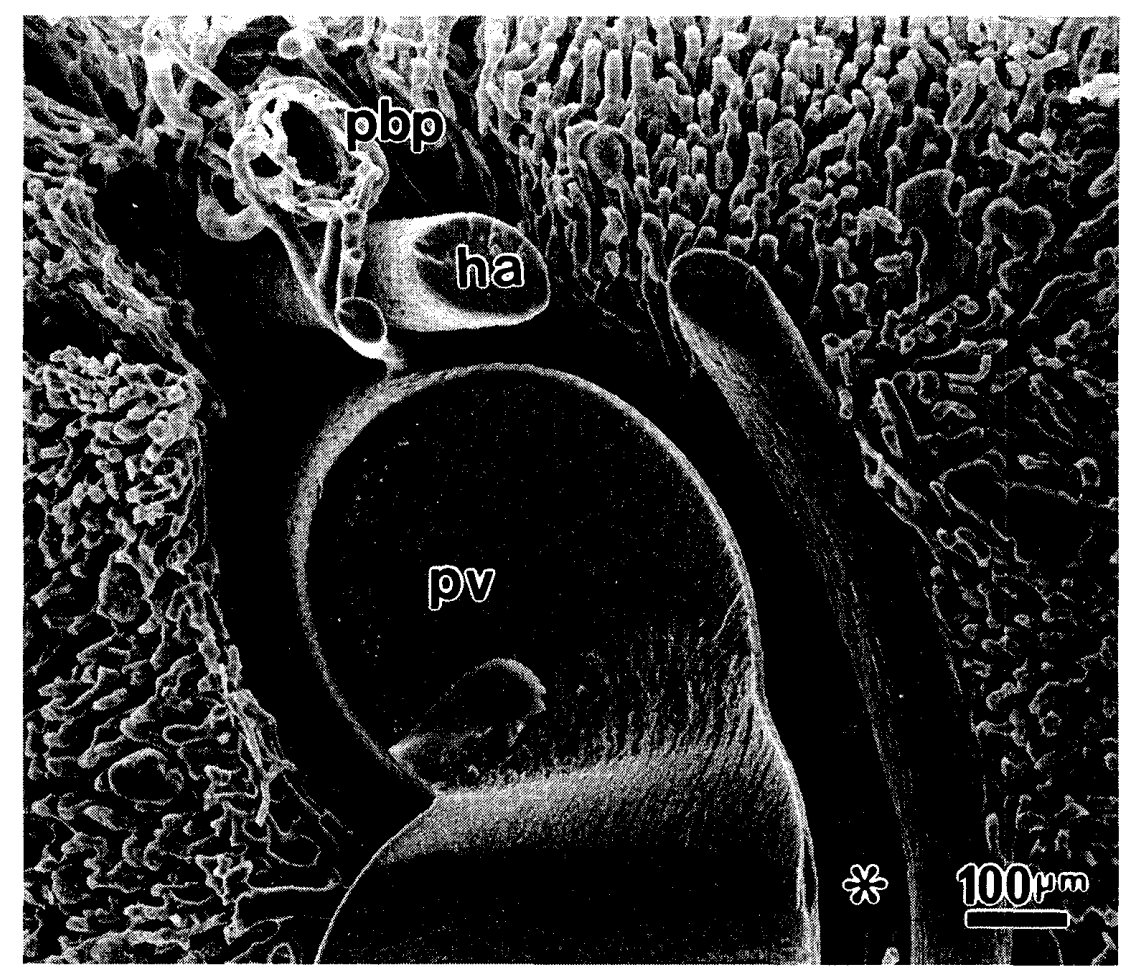

Fig. 3. Cross section of a portal tract. Peribiliary plexus is connected with a side branch of the portal vein. Note a periportal plexus $(*)$.

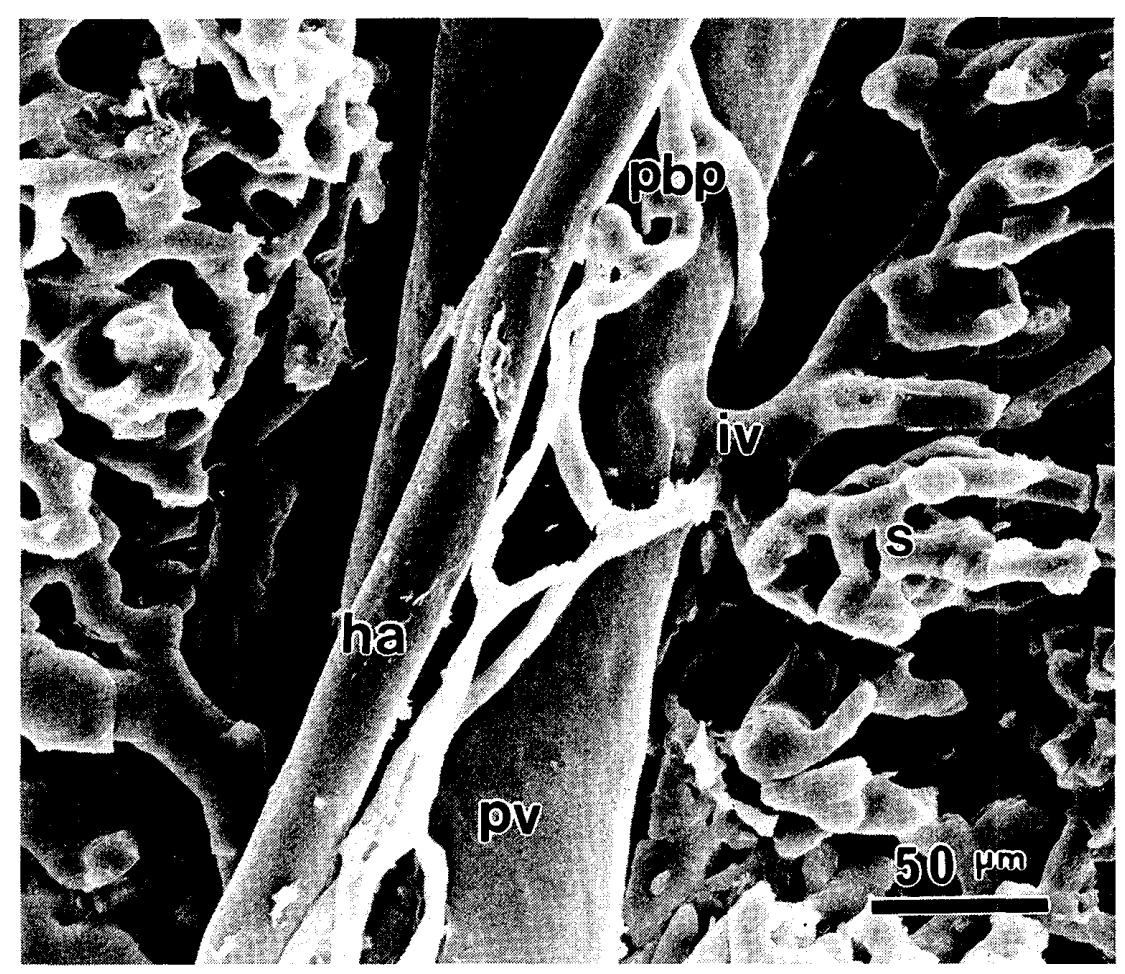

Fig. 4. A small portal tract. Peribiliary plexus is a sparse network of capillary vessels, one of which pours into the inlet venule (iv). 


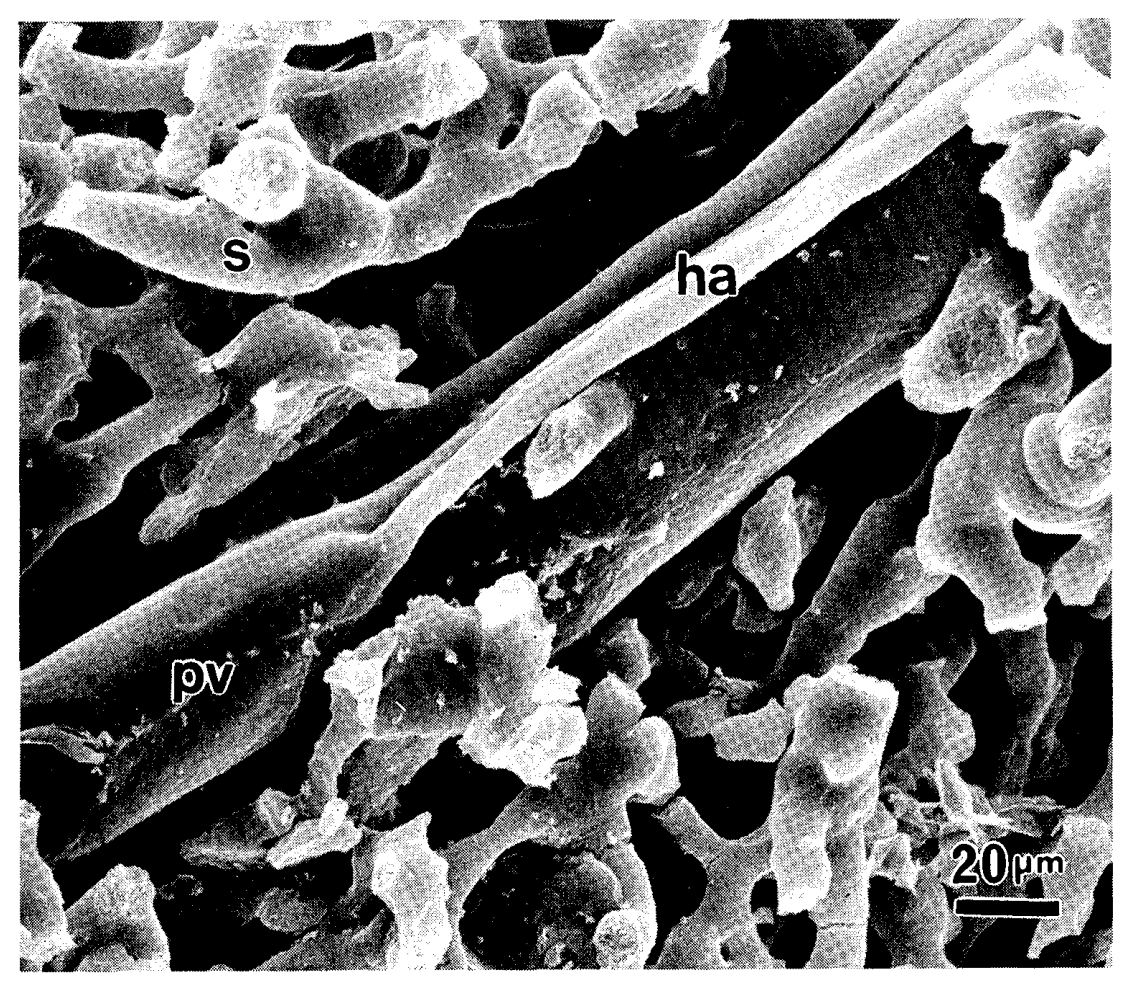

Fig. 5. Arterio-portal fistula in a small portal tract.

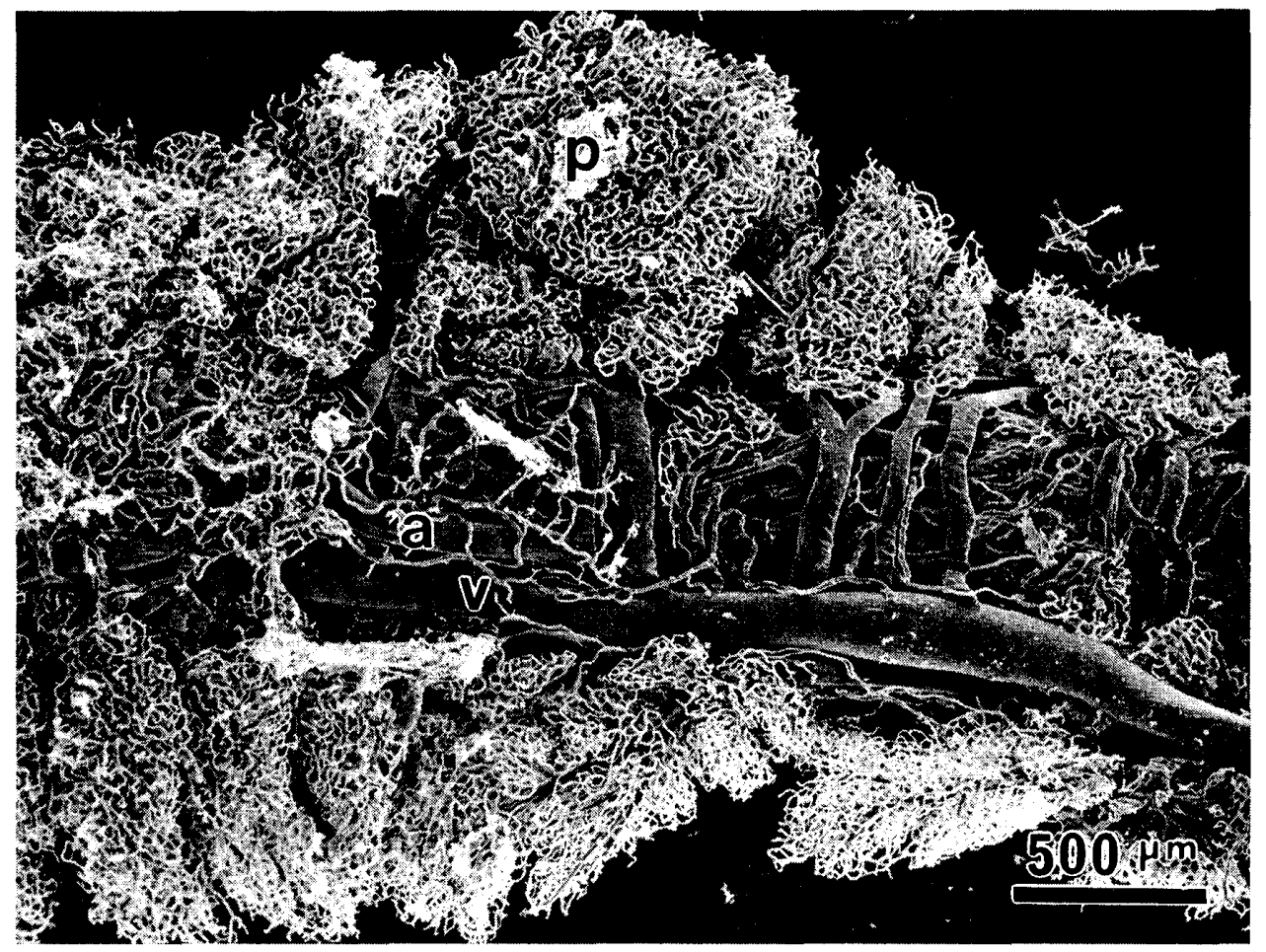

Fig. 6. Extrahepatic bile duct. An artery (a) and a vein (v) run parallel to the bile duct. Note fine capillary network of pancreatic tissue $(p)$. 


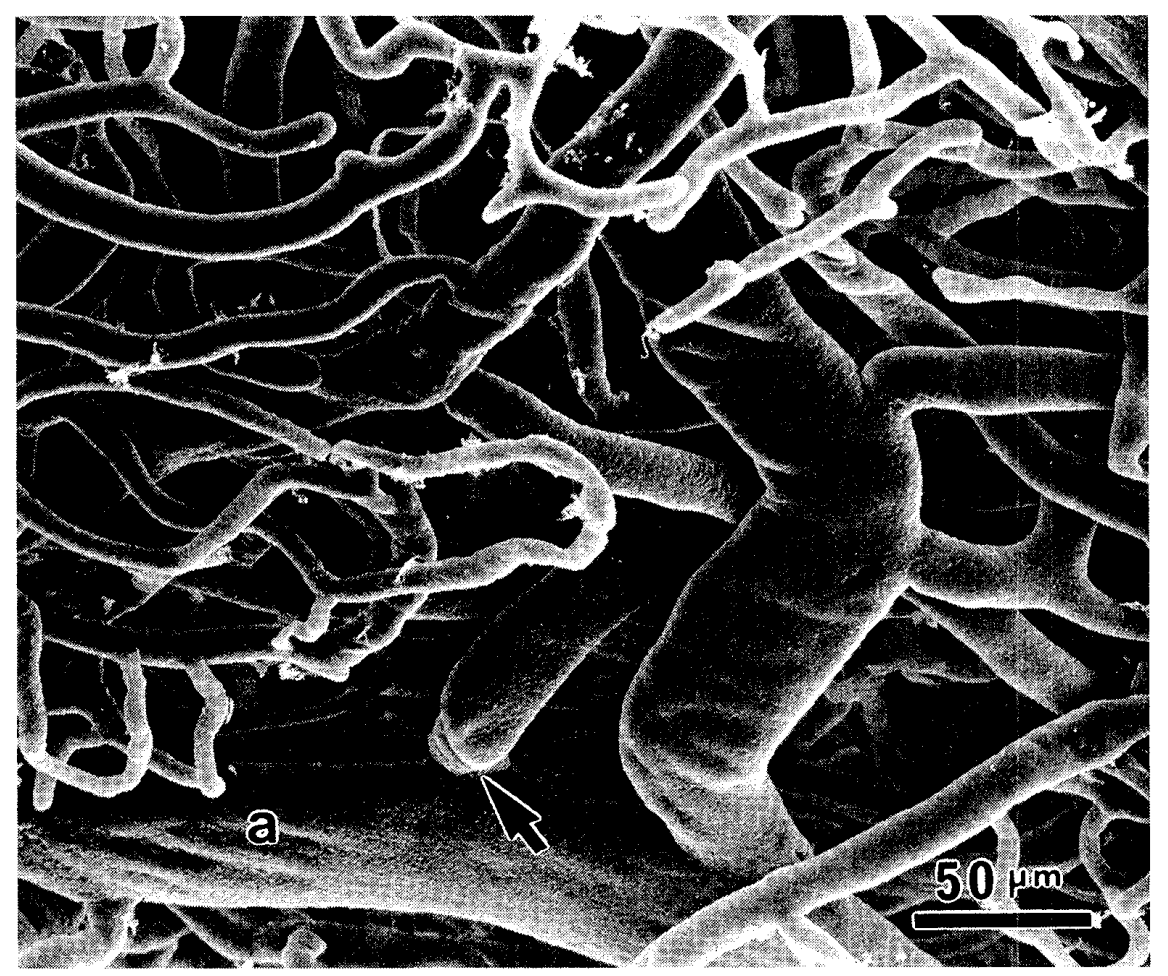

Fig. 7. Prominent stricture (arrow) at the branching site of the bile duct artery.

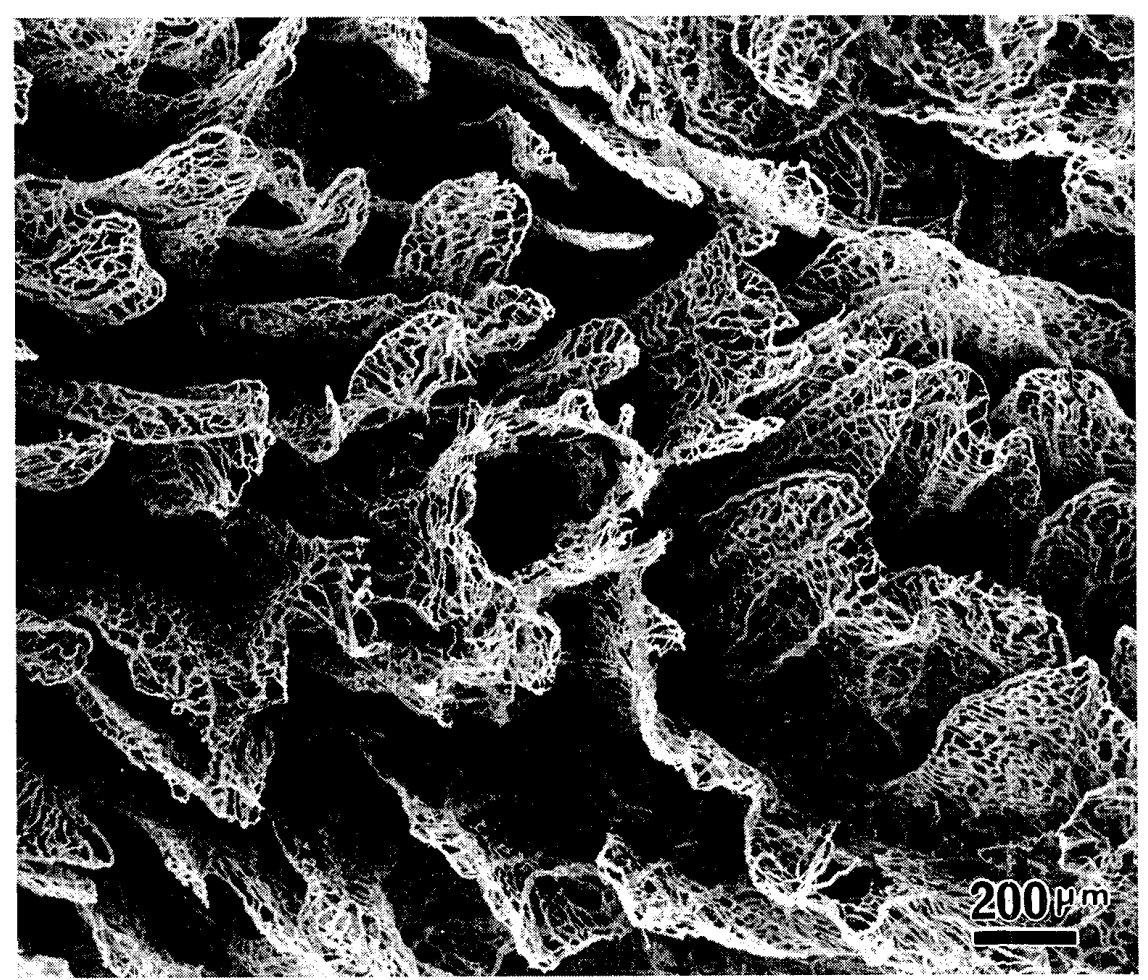

Fig. 8. Papilla vateri showing a small hole-like structure in numerous villi of the duodenal mucosa. 
was an opening of the common bile duct (Fig. 8). Somewhat large arterial and venous branches were distributed around the serosal side of the ampulla.

\section{Discussion}

The peribiliary plexus is one of the most complicated circulations in the liver. The plexus plays important roles not only in the physiologic state but also in pathologic conditions. In the cases of cirrhosis or extrahepatic portal obstruction, for example, dilated and increased plexuses have been noted, which might bear a collateral function (Cho \& Lunderquist, 1983; Terada et al., 1989).

Most investigators have argued for the fact that the hepatic artery gives off the afferent branches to the peribiliary plexus, which run into and supply the lobules (Andrews et al., 1949; Murakami et al., 1974; Yamamoto et al., 1985), and these findings were also confirmed in the course of our study. The connection of the peribiliary plexus with the portal vein was first described as "internal root" by Kiernan (1833), and has been supported thereafter by different methods such as the injection of Indian ink (Mitra, 1966) and the microvascular casting (Hase \& Brim, 1966; Ohtani, 1979). Similar connections were confirmed by the present study. In general, the internal root is regarded as the efferent route of the peribiliary plexus, where the blood flow is directed from the peribiliary plexus to the portal vein (Ohtani, 1979). However, Andrews et al. (1949) suggested the reverse direction, in which the peribiliary plexus was supplied by both hepatic artery and portal vein. Actually, we often encounter, in routine pathologic diagnosis, surviving bile ducts after therapeutic occlusions of the hepatic artery for hepatocellular carcinoma (transarterial embolization). A return flow from the portal vein to the peribiliary plexus may occur at least in some pathologic conditions. Murakami et al. (1974) denied the existence of the connection between the peribiliary plexus and the portal vein (internal root) in monkeys. This difference was thought to be a species-dependent variation (Ohtani et al., 1983).

Arterio-portal fistula has been confirmed by various methods and in various animals. Yamamoto et al. (1985) claimed that the arterio-portal fistula was seen in rat livers but not in hamsters nor in human livers. Mitra (1966), however, found the arterio-portal fistula in humans as well as in rats by the injection method of Indian ink, and speculated that fewer number of this anastomosis in humans than in rats might be mainly due to the postmortem occlusions of fine vessels, because human materials were obtained from cadavers. In the present study, numerous arterio-portal fistula were noted mainly in the peripheral portal tracts. Further examinations should be undertaken to clarify whether this anastomosis depends on the difference among species. Direct anastomosis of portal vein branches to hepatic vein branches, which were described in both experimental rat cirrhosis (Yogita, 1982) and clinical material of human cirrhosis (Hales et al., 1959), were not found in normal rat livers in the present study. Further examinations of the microvascular features of liver cirrhosis in experimental rats are now in progress in our laboratory. 


\section{References}

Andrews, W. H. H., Maegraith, B. G. \& Wenyon, G. E. M. (1949): Studies on the liver circulation. II. The micro-anatomy of the hepatic circulation. Ann. Trop. Med. Parasitol., 43: 229-237.

Cho, K. J. \& Lunderquist, A. (1983): The peribiliary vascular plexus: the microvascular architecture of the bile duct in the rabbit and in clinical cases. Radiology, 147: 357-364.

Elias, H. \& Petty, D. (1953): Terminal distribution of the hepatic artery. Anat. Rec., 116: 9-18.

Hales, M. R., Allan, J. S. \& Hall, E. M. (1959): Injection-corrosion studies of normal and cirrhotic livers. Am. J. Pathol., 35: 909-941.

Hase, T. \& Brim, J. (1966): Observation on the microcirculatory architecture of the rat liver. Anat. Rec., 156: 157-174.

Hojo, T., Hiramoto, Y. \& Nakashima, T. (1982): Some notes on branches of the pars umbilicalis trunci sinistri venae portae. Okajimas Folia Anat. Jpn., 59: 199-206.

Kardon, R. H. \& Kessel, R. G. (1980): Three-dimensional organization of the hepatic microcirculation in the rodent as observed by scanning electron microscopy of corrosion casts. Gastroenterology, 79: 7281.

Kiernan, F. (1833): The anatomy and physiology of the liver. Philos. Trans. R. Soc. Lond. [Biol.], 711770 .

Mitra, S. K. (1966): The terminal distribution of the hepatic artery with special reference to arterio-portal anastomosis. J. Anat., 100: 651-663.

Murakami, T. (1971): Application of the scanning electron microscope to the study of the fine distribution of the blood vessels. Arch. histol. jap., 32: 445-454.

Murakami, T., Itoshima, T. \& Shimada, Y. (1974): Peribiliary portal system in the monkey liver as evidenced by the injection replica scanning electron microscope. Arch. histol. jap., 37: 245-260.

Ohtani, O. (1979): The peribiliary portal system in the rabbit liver. Arch. histol. jap., 42: 153-167.

Ohtani, O., Kikuta, A., Ohtsuka, A. et al., (1983): Microvasculature as studied by the microvascular corrosion casting/scanning electron microscope method. I. Endocrine and digestive system. Arch. histol. jap., 46: 1-42.

Olds, J. M. \& Stafford, E. S. (1930): On the manner of anastomosis of the hepatic and portal circulations. Bull. Johns Hopkins Hosp., 47: 176-185.

Rappaport, A. M. (1980): Hepatic blood flow: morphological aspects and physiological regulation. Int. Rev. Physiol., 21: 1-63.

Terada, T., Hoso, M. \& Nakanuma, Y. (1989): Microvasculature in the small portal tracts in idiopathic portal hypertension. A morphological comparison with other hepatic diseases. Virchows Arch. [Pathol. Anat.], 415: 61-67.

Yamamoto, K., Sherman, I., Phillips M. J. et al. (1985): Three-dimensional observations of the hepatic arterial terminations in rat, hamster and human liver by scanning electron microscopy of microvascular casts. Hepatology, 5: 452-456.

Yogita, S. (1982): Experimental studies on thioacetamide-induced cirrhosis in rat. Changes of various stages in hepatic and portal venous systems. Shikoku Med. J., 38: 241-254. 
ラット肝・胆管血管鋳型の走査電顕像

原武 譲二・山元 修・久岡 正典・堀江 昭夫 産業医科大学第一病理学教室

要 旨： 正常ラット肝ならびに胆管の微小血管を，血管鋳型ならびに走査電子顕微鏡（SEM）を用 いて検索した．血管鋳型は生食水にて灌流後, Mercox を注入して得られた，門脈枝は順 次二分岐して径を減じ終末門脈から類洞へ注ぐ他，多数の小側枝を分枝し，これらはしば しば動脈枝を伴わず, 直接類洞へ注いでいた. 胆管周围には豊富な血管網 (PBP) が見られ, 肝動脈からの輸入血管を受け，門脈枝や類洞への灌流，阴脈周国血管網との吻合もみられ た．末梢門脈域では，肝動脈門脈吻合や肝動脈類洞吻合がみられる他，PBP と類洞の吻 合もみられた，肝内血管網は極めて複雑な吻合や分枝を示し，動脈と門脈によるに二重支 配をさらに円滑にしていることが示唆された．肝外胆管や，今までに記載の少ない Vater 乳頭の血管網にも触れ, 若干の文献的考察を行った。

J. UOEH (産業医大誌), 12 (1): 19-28 (1990) 